\title{
KESANTUNAN KONVIVAL PADA MASYARAKAT BANJAR DI KELURAHAN SEKUMPUL, MARTAPURA
}

\author{
(LANGUAGE POLITENESS IN CONVENTIONAL SPEECH ACTS IN BANJAR \\ SOCIETY IN VILLAGES SEKUMPUL, MARTAPURA)
}

\author{
Rissari Yayuk \\ BALAI BAHASA PROVINSI KALIMANTAN SELATAN \\ Jln. A. Yani. Km. 32,2, Lok Tabat, Banjarbaru, Kalimantan Selatan \\ Pos-el: yrissariyayuk@yahoo.co.id
}

Diterima: 21 Agustus 2017; Direvisi: 17 Oktober 2017; Disetujui: 31 Oktober 2017

\begin{abstract}
The purpose of this research is to study the socially-oriented culture with the social or Banjar convention that is connected with the theory of language politeness based on pragmatic science. The problem in this research is how to form the politeness of speech acts convulsive language in Banjar society in Sekumpul Village, Martapura. This study used qualitative method. The author took three steps of work, namely the stage of data collection, data processing, and presentation of data analysis. Techniques used in data retrieval are recording and documentation techniques. Data analysis method is a method of matching. Data analysis techniques are the basic techniques of dividing as a distinguishing reaction and hearing rate. The result of this division will be obtained by analytical unit according to what is meant by theory in literature review. Theories that become data analysis based on pragmatic science point of view. Presentation of datais using ordinary words.Research location was in Sakumpul Village, Banjar District, South Kalimantan Province. The study was conducted from January--June 2016. The result of the research showed that the form of convivial speech acts convulsive in Banjar society in Sekumpul Subdistrict, Martapura, consisted of conventional speaking speech acts convention offers, approves, apologizes, praises, approves, invites, Say hello, and congratulate.
\end{abstract}

Keywords: politeness, convention, Banjar

\begin{abstract}
Abstrak
Tujuan penelitian ini adalah mengkaji budaya santun berbahasa masyarakat dengan tujuan sosial atau konvival Banjar yang dihubungkan dengan teori kesantunan berbahasa berdasarkan ilmu pragmatik. Permasalahan dalam penelitian ini adalah bagaimana wujud kesantunan berbahasa tindak tutur konvival dalam masyarakat Banjar di Kelurahan Sekumpul, Kabupaten Martapura. Penelitian ini menggunakan metode kualitatif. Penulis menempuh tiga langkah kerja, yaitu tahap pengumpulan data, pengolahan data, dan tahap penyajian hasil analisis data. Teknik yang digunakan dalam pengambilan data adalah teknik rekam dan dokumentasi. Analisis data menggunakan metode padan. Teknik analisis data adalah teknik dasar pilah sebagai pembeda reaksi dan kadar keterdengaran. Hasil dari daya pilah ini akan diperoleh satuan analisis yang sesuai dengan apa yang dimaksudkan oleh teori
\end{abstract}


dalam kajian literatur.Teori yang menjadi analisis data berdasarkan sudut pandang ilmu pragmatik. Penyajian data dengan menggunakan kata-kata biasa.Lokasi penelitian di Kelurahan Sakumpul, Kabupaten Banjar, Provinsi Kalimantan Selatan. Penelitian dilakukan dari bulan Januari-Juni 2016. Hasil penelitian menunjukkan bahwa wujud kesantunan berbahasa tindak tutur konvival dalam masyarakat Banjar di Kelurahan Sekumpul, Kabupaten Martapura, terdiri atas kesantunan berbahasa tindak tutur konvival menawarkan, menyetujui, meminta maaf, memuji, menyetujui, mempersilahkan, menyapa, dan mengucapkan selamat.

Kata Kunci: kesantunan, konvival, Banjar

\section{Pendahuluan}

Pada tanggal 10 bulan 11 tahun 2016, Menteri agama Lukman Hakim Saifuddin mengatakan dalam pidatonya di Forum Kebudayaan Dewan Kesenian Jakarta (DKJ) di Taman Ismail Marzuki bahwa sopan santun merupakan salah satu budaya bangsa yang luhur. Pernyataan menteri agama ini menegaskan bahwa kesantunan merupakan sesuatu yang sangat penting dalam kehidupan berbangsa. Hal ini dibuktikan di sepanjang tahun 2016-2017, terdapat berita-berita pelaporan ke lembaga hukum dari beberapa pihak kepada pihak-pihak tertentu akibat bahasa yang tidak santun. Akibat bahasa yang tidak santun ini tidak hanya melanda kalangan pejabat, masyarakat dan pelajar pun turut merasakannya. Perkelahian antarpelajar adalah salah satu wujud tidak diperhatikannya masalah kesantunan berbahasa.

Berkaitan dengan masalah kesantunan berbahasa ini, seorang peneliti bahasa, Yusri (2016:104) menyatakan bahwa masalah kesantunan berbahasa kiranya mendapatkan perhatian lebih, baik oleh pakar atau linguis, maupun para pembelajar bahasa. Melalui pemahaman ini, nantinya seseorang akan lebih sopan dalam berbahasa dengan mitra tutur. Sementara, KBBI (2008:1224) menyatakan bahwa santun berbahasa adalah halus dan baik budi bahasanya; sabar; tenang; sopan; penuh belas kasih saat berbicara.

Berdasarkan hal ini, pendokumentasian tentang kesantunan berbahasa penting sekali., khususnya kesantunan berbahasa dalam bahasa daerah. Mengingat, bahasa daerah sekarang banyak mengalami pengaruh dari bahasa luar. Bahasa daerah yang mendapat pengaruh bahasa luar daerah ini kemungkinan kosakatanya yang berkaitan dengan masalah kesantuanan, seperti kata sapaan, panggilan kekerabatan, ucapan khusus untuk menyebut pihak tertentu secara santun, dan lain-lain akan hilang. Melalui kajian kesantunan, akan ditemukan ragam bahasa yang dimaksud. Hal ini akan menjadi salah satu materi referensi tentang kesantunan berbahasa.

Masyarakat Banjar adalah bagian dari masyarakat di Indonesia. Bahasa ini sudah mulai tergantikan oleh bahasa Indoensia untuk penutur yang berada di perkotaan. Budaya 
tradisional Banjar tentu mulai mengalami pergeseran pula. Hal ini dapat dilihat pada wilayahwilayah pemukiman di tengah kota Banjarmasin, ibu kota Provinsi Kalimantan Selatan. Berdasarkan pengamatan peneliti, di wilayah ini budaya saling tegur sapa dalam menjalin hubungan sosial mulai tergantikan dalam kesehariannya dengan sikap acuh tidak acuh. Hanya waktu-waktu tertentu saja, seperti ada acara hajatan, ulang tahun kota, dan hari kemerdekaan, akan terlihat kembali saling bertegur sapa sesama warga.

Masyarakat Banjar yang berada di pinggir kota Banjarmasin merupakan salah satu penutur bahasa yang masih menjunjung budaya tradisional santun berbahasa. Dalam keseharian mereka, saling bertegur sapa, saling mengingatkan, saling memuji, dan lain sebagainya adalah bagian yang tidak terpisahkan saat bersosialisai, baik di ranah keluarga maupun ranah masyarakat. Rekaman sebagian budaya santun berbahasa inilah yang peneliti jadikan kajian penelitian ini dengan berlandaskan teori kesantunan berbahasa dengan sudut pandang ilmu pragmatik. Kridalaksana (2008:198) menyatakan bahwa ilmu pragmatik adalah ilmu yang menyelidiki pertuturan, konteks, dan maksudnya. Tarigan (2009:25) menyatakan bahwa pragmatik adalah suatu telaah makna dalam hubungannya dengan aneka situasi ujaran. Pragmatik diperlukan dalam menganalisis makna yang dipertuturkan oleh penutur disesuaikan dengan situasi ujar. Situasi ujar ini meliputi penutur dan lawan tutur, konteks tuturan, tujuan tuturan, dan tuturan sebagai tindak verbal.

Masalah yang akan dibahas dalam penelitian ini meliputi wujud kesantunan konvival pada masyarakat Banjar di Kelurahan Sekumpul, Martapura. Tujuan penelitian adalah untuk mendeskripsikan wujud kesantunan konvival pada masyarakat Banjar di Kelurahan Sekumpul, Martapura. Adapun penelitian lain, khusus bahasa Banjar, yaitu Jahdiah pada tahun 2013 dengan judul "Prinsip Kerja sama dalam Transaksi Jual Beli di Pasar Martapura" mengupas penerapan dan penyimpangan kesantunan berbahasa pada skala Leech dalam tuturan penjual dan pembeli. Penelitian Zaini (2008) yang berjudul "Kesantunan Direktif Bahasa Banjar” mengupas kesantunan berbahasa direktif pada bahasa Banjar.

Hasil Penelitian ini mendeskripsikan mayarakat Banjar yang berada di Kelurahan Sekumpul sebagai salah satu contoh penutur bahasa yang masih menggunakan kesantunan berbahasa saat menjalin komunikasi dengan sekitar dengan tujuan sosial yang baik.

\section{Kerangka Teori}

Tindak tutur atau speech act merupakan suatu tindakan yang diungkapkan melalui bahasa yang disertai dengan gerak dan sikap anggota badan untuk mendukung maksud pembicara. Tindak tutur ditentukan oleh adanya beberapa aspek situasi ujar, antara lain 
(1) yang menyapa (penutur) dan yang disapa (petutur); (2) latar belakang; (3) tujuan sebuah tuturan; (4) bentuk tindak kegiatan; dan (5) produk tindak verbal (Leech dalam Jumadi, 2006:115). Rahardi (2009:17) menyebutkan bahwa ada lima bentuk tindak tutur yang dilakukan orang sewaktu memproduksi ujaran, dilihat dari fungsi ilokusinya. Menurut Searle (dalam Ibrahim, 1993:27), bentuk tuturan dan kategori tindakan yang dilakukan oleh seseorang adalah sebagai berikut.

1) Tindak tutur asertif atau yang biasa juga disebut tindak tutur representatif adalah tindak tutur yang berkaitan dengan menyatakan sesuatu. Tindak tutur ini mengikat penuturnya akan kebenaran atas apa yang diujarkan. Bentuk tindak tutur ini biasanya dilakukan orang sewaktu dia mengemukakan pendapat/menyatakan sesuatu, berspikulasi, mengklaim, dan melaporkan;

2) Tindak tutur direktif adalah tidak tutur yang dimaksudkan agar lawan bicara melakukan sesuatu. Fungsinya seperti meminta, menyarankan, melarang, serta memerintah;

3) Tindak tutur komisif adalah jenis tindak tutur yang penuturnya berjanji untuk melakukan sesuatu. Tindak tutur ini memiliki fungsi seperti berjanji, bersumpah, dsb;

4) Tindak tutur ekspresif adalah bentuk tindak tutur yang diutarakan untuk mengungkapkan perasaan penutur terhadap sesuatu keadaan. Fungsinya seperti berterima kasih, memberi ucapan selarnat atau bela sungkawa, meminta maaf, menyalahkan, memuji, dsb;

5) Tindak tutur deklaratif adalah bentuk tindak tutur yang kebenarannya berhubungan dengan isi proposisi dan kenyataannya. Tindak tutur ini lazimnya diutarakan oleh orangorang yang memiliki kewenangan untuk melakukan tindakan itu. Fungsinya seperti memberhentikan, mengundurkan diri, menghukum, memberi nama, membaptis, dsb. Bila tindak tutur ini diutarakan oleh orang-orang yang tidak memiliki kewenangan dalam kerangka institutional, tindak tutur itu dianggap tidak valid (infelicitous).

Selanjutnya, tindak tutur ini berdasarkan tujuannya ada yang disebut dengan tutur konvival. Tindak tutur ini memiliki tujuan sosial. Contoh tindak tutur ini adalah mengungkapkan rasa belasungkawa kepada seseorang yang ditimpa musibah dengan kata turur berduka cita. Baryadi (2013:31--32) menyatakan bahwa tindak tutur konvival adalah tindak tutur yang sejalan dengan tujuan sosial. Tindak tutur konvival meliputi tuturan menyapa, berbela sungkawa, berterimakasih, menyanjung, bercanda, dan lain-lain.

Pustaka acuan yang berkaitan dengan kajian tentang tindak tutur yang bertujuan sosial atau konvival ini ditegaskan oleh Anwar (1984), bahwa tindak tutur bertujuan sosial, contohnya adalah basa basi. Basa-basi ialah kata-kata yang berfungsi sebagai pemertahanan suasana yang baik saat penutur bahasa berada dalam satu waktu dan satu tempat. Selanjutnya, 
Arimi (1998) menyatakan bahwa kata-kata mempertahankan suasana yang baik ini terdiri atas basa-basi murni yang sesuai dengan kenyataan dan basa-basi yang tidak sesuai dengan kenyataan.

Berhubungan dengan aturan kesantunan berbahasa ini, Chaer dan Leonie Agustina (2010:172) menyatakan bahwa kesantunan berbahasa antara lain "mengatur " (1) apa yang harus kita katakan pada waktu dan keadaan tertentu kepada seorang partisipan tertentu yang berkenaan dengan status sosial dan budaya dalam masyarakat itu; (2) ragam bahasa apa yang paling wajar kita gunakan dalam situasi sosiolinguistik dan budaya tertentu; (3) kapan dan bagaimana kita menggunakan giliran berbicara kita, dan menyela pembicaraan orang lain; (4) kapan kita harus diam; dan (5) bagaimana kualitas suara dan sikap fisik. Selanjutnya, Geertz (1960) (dalam Yayuk, 2012:173) menyatakan bahwa prinsip atau sistem penggunaan bahasa yang mendasari kesantunan berbahasa dapat disebut "sopan-santun berbahasa" atau honorifics ini lazim diungkapkan dengan kata ganti orang, sistem sapaan, penggunaan gelar dan sebagainya. Dalam beberapa bahasa, perbedaan tingkat sosial antara pembicara dengan si alamat/pendengar diwujudkan dalam seleksi kata dan/atau sistem morfologi kata-kata tertentu.

Leech (dalam Jumadi, 2006:76) secara detail menyatakan beberapa aturan atau maksim dalam prinsip kesantunan, yaitu (1) maksim kebijakan yang mengutamakan kearifan bahasa, (2) maksim penerimaan yang mengutamakan keuntungan untuk orang lain dan kerugian untuk diri sendiri, (3) maksim kemurahan yang mengutamakan kesalutan/rasa hormat pada orang lain dan rasa kurang hormat pada diri sendiri, (4) maksim kerendahan hati yang mengutamakan pujian pada orang lain dan rasa rendah hati pada diri sendiri, (5) maksim kecocokan yang mengutamakan kecocokan pada orang lain, dan (6) maksim kesimpatisan yang mengutamakan rasa simpati pada orang lain. Dengan menerapkan prinsip kesopanan ini, orang tidak lagi menggunakan ungkapan-ungkapan yang merendahkan orang lain sehingga komunikasi akan berjalan dalam situasi yang kondusif.

Brown dan Levinson (dalam Wijana, 2011:135--136) menjelaskan bahwa terdapat beberapa strategi kesantunan yang dapat dilakukan, seperti membesar-besarkan perhatian, persetujuan, dan simpati kepada pendengar, melibatkan penutur dan pendengar dalam aktivitas, menggunakan penanda identitas kelompok (bentuk sapaan, dialek, jargon, menunjukkan keoptimisan, menggunakan lelucon, memberikan tawaran atau janji, memberikan pertanyaan atau meminta alasan, menyatakan hubungan secara timbal balik (resiprokal), dan memberikan hadiah (barang, simpati, perhatian, kerja sama) kepada mitra tutur. 


\section{Metode Penelitian}

Penelitian ini menggunakan metode deskriptif kualitatif. Metode yang digunakan adalah metode deskriptif. Penggunaan metode ini didasarkan pada pengumpulan data penelitian berdasarkan natural setting. Artinya, metode yang digunakan semata-mata berdasarkan fakta kebahasaan yang ada. Metode ini menggambarkan fenomena yang terjadi pada tuturan yang ada secara empiris. Hal ini sesuai dengan pendapat Djajasudarma (2006:24) yang mengatakan bahwa data yang digunakan bersifat akurat dan alamiah.

Sugiono (2011:8) menyatakan bahwa metode kualitatif merupakan metode yang hasil penelitiannya berkenaan dengan interpretatif data. Penulis menempuh tiga langkah kerja, yaitu tahap pengumpulan data, pengolahan data, dan tahap penyajian hasil analisis data. Hal ini sesuai pula dengan yang dimaksudkan Sudaryanto (2015:57).

Teknik yang digunakan dalam pengambilan data adalah teknik rekam dan dokumentasi. Metode analisis data adalah metode padan. Metode ini berdasarkan alat penentunya di luar bahasa, seperti mitra bicara, tulisan, dan referen bahasa. Data yang dihasilkan berupa deskripsi penggunaaan bahasa penuturnya. Teknik analisis data adalah teknik dasar pilah sebagai pembeda reaksi dan kadar keterdengaran. Peneliti memilah data mentah berdasarkan reaksi penutur dan mitra tutur dan berdasarkan kualitas fisik dan suara yang didengar.

Sudaryanto (2015:25--30) menyatakan bahwa metode analisis data padan adalah alat penentunya terlepas dari unsur bahasa sendiri. Teknik pilah berdasarkan pembeda reaksi dan kadar kedengaran adalah teknik analisis data yang berkaitan dengan mitrra bicara dan apa yang terdengar, seperti tindakan tuturan, isi tuturan, emosi, reaksi anggota tutur, kualitas suara dan wujud fisik penutur. Hasil dari daya pilah ini akan diperoleh satuan analisis yang sesuai dengan apa yang dimaksudkan oleh teori dalam kajian literatur.

Selanjutnya, teori yang menjadi analisis data berdasarkan sudut pandang pragmatik. Penyajian data dengan menggunakan kata-kata biasa. Lokasi penelitian di Kelurahan Sakumpul, Kecamatan Martapura, Kabupaten Banjar, Provinsi Kalimantan Selatan. Penelitian dilakukan dari bulan Januari-Juni 2016. Selama itu, peneliti beriteraksi dengan masyarakat Banjar di lingkungan Kelurahan Sekumpul. Alasan pemilihan wilyah ini karena di sini berkumpulnya masyarakat Banjar dari berbagai wilayah di luar Sekumpul. Di daerah ini banyak tempat pengajian agama yang diadakan hampir setiap hari. Di tambah lagi, di daerah ini terdapat makam ulama besar Kalimantan Selatan, Kyai Haji Izai atau guru Sekumpul sehingga Sekumpul menjadi padat penduduknya. Sekumpul menjadi salah satu wilayah ziarah yang sering dikunjungi oleh masyarakarat Banjar, baik dari kota maupun desa. 
Sementara itu, alasan peneliti hanya membutuhkan tiga bulan karena data yang diperoleh dianggap sudah cukup memenuhi apa yang peneliti inginkan.

\section{Pembahasan}

\subsection{Kesantunan Berbahasa Tindak Tutur Konvival Menawarkan}

Data [1]

Tetangga 1: Hui handak rambutankah? Nyaman kuputikiakan nah. Tampulu aku maunduhnya. Jangan supan-supan kawanai.

'Hei ingin rambutankah? Biar kupetikkan nah. Mumpung aku memanennya. Jangan malu-malu kawan'.

Tetangga 2: Oh iyakah makasih. Handak ka padang nah.

'Oh iya terimakasih. Mau ke sawah nah'

Konteks tuturan: Tuturan terjadi di area kebun rambutan antara dua tetangga yang sudah akrab.

Data [1] ini merupakan contoh penggunaan tindak tutur konvival. Tetangga (1) melakukan aktivitas menawarkan kepada tetangga (2). Saat itu, tetangga (1) sedang memanen rambutan di kebunnya. Kebun tersebut terletak di tepi jalan desa menuju persawahan penduduk yang cukup luas. Secara kebetulan, tetangganya melewati jalan tersebut. Melihat tetangga akrabnya itu sedang berjalan di jalan desa, sementara dia berada di atas pohon rambutan yang buahnya sangat lebat, keluarlah ungkapan menawarkan tersbeut: Hui handak rambutankah? Nyaman kuputikiakan nah. Tampulu aku maunduhnya. Jangan supan-supan kawanai. 'Hei ingin rambutankah? Biar kupetikkan nah. Mumpung aku memanennya. Jangan malu-malu kawan'.

Ujaran menawarkan dari tetangga [1) kepada tetangga (2) berdasarkan situasi ujar terdiri atas penyapa, yaitu tetangga [1] dan yang disapa tetangga (2). Tujuan tuturan adalah untuk menawarkan buah rambutan yang dipanen tetangga (1). Bentuk kegiatan tuturan basa basi murni berdasarkan kenyataan. Produk tindak verbalnya adalah tindak tutur direktif menawarkan. Kondisi ini sesuai dengan apa yang dimaksudkan Leech dalam Jumadi $(2006: 115)$

Selanjutnya, data [1] ini mencerminkan budaya kesantunan berbahasa masih dilakukan oleh masyarakat Sekumpul sebagai wujud rasa kebersamaan untuk saling berbagi. Berdasarkan prinsip kesantunan berbahasa, budaya ini dilaksanakan dengan maksim penerimaan sebagaimana yang dimaksudkan Leech dalam Jumadi (2006:76). Maksim penerimaan adalah ketika berbahasa penutur lebih mengutamakan keuntungan untuk orang 
lain dan kerugian untuk diri sendiri. Artinya, ketika tetangga (1) menawarkan rambutan kepada tetangga (2) dia tidak memperhitungkan untung rugi, meskipun sebenarnya tetangga (1) tersebut merupakan seorang penjual buah-buahan, termasuk hasil kebunnya sendiri. Dengan demikian, tetangga (1) menggunakan maksim penerimaan ini karena dia memiliki anggapan bahwa berbagi dengan sesama merupakan sebuah hal yang wajar, dia menerima anggapan tersebut ketika melakukan kegiatan berbahasa.

Aturan yang terdapat dalam kesantunan berbahasa sebagaimana yang dimaksudkan Chaer dan Leonie Agustina ( 2010:172) terdapat pada data [1]. Tetangga (1) melakukan apa yang harus dikatakan pada waktu melihat tetangga (2) ketika dia sedang memetik buah rambutan di kebunnya. Apa yang dilakukannya ini memang bagian dari budaya masyarakat Banjar pada umumnya. Bahasa yang dia gunakan adalah bahasa santai dengan menggunakan bahasa daerah Banjar. Bahkan dia menyatakan agar tetangga (2) tidak usah malu-malu menerima tawarannya tersebut. Tetangga (1) mengujarkan tuturannya dengan diiringi senyum di wajahnya dan intonasi suara biasa. Kualitas fisik dan intonasi suara ini bagian yang bisa juga menentukan sebuah bahasa santun atau tidak.

Berdasarkan strategi kesantunan berbahasa, tetangga (1) melakukan strategi kesantunan dengan memberikan tawaran atau janji sebagaimana yang dimaksudkan Brown dan Levinson (dalam Wijana, 2011:135--136). Tetangga (1) melakukan tawaran kepada tetangga (2) dan dia menjanjikan akan mengambilkan rambutan tersebut jika tetangga (2) mau menerima tawarannya. Strategi ini merupakan salah satu upaya yang dilakukan tetangga (1) dalam mewujudkan kesantunan berbahasa untuk mencapai hubungan sosial yang baik.

Selanjuntnya, tanggapan tetangga (2) sebagai pihak yang disapa oleh tetangga (1) terlihat baik. Tanggapan yang diberikan oleh tetangga (2) terhadap kesantunan berbahasa terhadap tetangga (1) juga menunjukkan kalau dia juga melakukan kesantunan berbahasa yang sama. Tetangga (2) mengucapkan kata terimakasih sebagai ungkapan menghargai atas upaya tawaran yang diberikan tetangga (1) kepadanya. Dalam kondisi ini, terlihat bahwa sebuah hubungan sosial akan terjadin melalui komunikasi yang santun. Hal inilah yang dimaksudkan oleh Rahardi (2009:220) bahwa tindak tutur yang berdemensi sosial ini akan berjalan dengan baik jika terjadi kerja sama yang kuat antarpeserta tutur. Salah satu bentuk kerja sama tersebut adalah dengan berprilaku sopan dan santun. 


\subsection{Kesantunan Berbahasa Tindak Tutur Konvival Terima Kasih dan Memuji}

Data [2]

Bibi : "Tarimakasih banar lah nang samalam. Umaai nyaman banar hundang masak kuningnya. Paman ikam wan ading ikam sampai mandua piring makan.Makasiihlah, jangan jaralah”.

'Terimakasih sekali ya yang kemarin. Aduh enak sekali masak udang kuningnya. Paman kamu dengan adikmu sampai dua piring makannya. Terimakasih ya, jangan jera'.

Keponakan : "Umai Piyan nih bisa banar. Pintar banar mahimungi. Ayu ja mun dipuji nih, bisa ulun antari lagi nih”.

'Aduh Anda ini bisa sekali. Pandai sekali menyenangi. Ayo kalau dipuji ini, bisa saya antari lagi nih'.

Konteks tuturan: Tuturan terjadi antara seorang bibi dengan keponakannya di depan rumah salah satu warga masyarakat Banjar Kelurahan Sekumpul.

Data [2] merupakan contoh penggunaan tindak tutur yang memiliki tujuan sosial. Bibi melakukan kegiatan bertutur mengucapkan rasa terimakasih sekaligus melakukan pujian kepada keponakannya. Saat itu, Bibi sedang naik sepeda dan keponakan berjalan kaki dengan arah berlawanan di jalan Kelurahan Sekumpul. Melihat keponakannya tersebut, Bibi turun dan berhenti tepat di depan keponakannya tersebut. Bibi langsung mengucapkan: "Tarimakasih banar lah nang samalam. Umaai nyaman banar hundang masak kuningnya. Paman ikam wan ading ikam sampai mandua piring makan.Makasiihlah, jangan jaralah”, 'Terimakasih sekali ya yang kemarin. Aduh enak sekali masak udang kuningnya. Paman, kamu, dan adikmu, sampai dua piring makannya. Terimakasih ya, jangan jera'.

Situasi ujar yang terjadi pada data [2] terdiri atas pesapa, bibi dan yang disapa, keponakan. Tuturan ini memiliki tujuan untuk mengucapkan rasa terimakasih dan pujian terhadap keponakannya. Bentuk kegiatan adalah tuturan yang berisi tentang informasi pujian dan rasa terimakasih dari Bibi kepada keponakannya. Produk tindak verbal dalam data [2] ini berupa tindak tutur ekspresif terima kasih dan pujian.

Budaya memberikan pujian dan ucapan terimakasih dari Bibi kepada keponakannya ini mencerminkan budaya santun berbahasa dalam keluarga Banjar. Bibi mengucapkan rasa terimakasih dan memuji hasil masakan keponakannya yang telah membuat anak dan suaminya berselera makan hingga dua piring. Bibi melakukan tindak tutur tersebut dengan harapan menjalin hubungan sosial yang baik dengan keponakannya sebagai sesama kerabat. Tidak ada rasa malu dari bibi untuk melakukan pujian terhadap pihak yang lebih muda 
usianya. Bibi memiliki jiwa rendah hati. Hal ini berarti bibi telah melakukan pelaksanaan kesantunan berbahasa dengan prinsip maksim kerendahan hati sebagaimana yang dimaksudkan Leech (dalam Jumadi, 2006:76). Maksim kerendahan hati adalah mengutamakan pujian pada orang lain dan rasa rendah hati pada diri sendiri.

Berdasarkan data yang terekam oleh penulis, saat itu, suasana pertemuan antara bibi dan keponakan terlihat hangat dan menyenangkan.Wajah sumringah memancar di kedua penutur. Bibi telah berhasil menciptakan suasana yang baik kala kejadian tersebut terjadi tanpa direncanakan. Bibi menyampaikan perasaannya tentang kenyataan bahwa masakan sang keponakan memang enak. Hal ini pula yang sesuai dengan apa yang dimaksudkan oleh Rahardi (2017:11) bahwa tindak tutur yang bertujuan sosial ini atau disebut dengan bahasa kefatisan merupakan sesuatu yang sangat penting kehadirannya demi kelancararan komunikasi.

Kesantunan berbahasa yang bertujuan sosial sebagaimana yang dilakukan bibi merupakan contoh tuturan warga Banjar saat berkomunikasi. Bibi dalam rangka melaksanakan kesantunan tersebut, menggunakan kesantunan berbahasa berupa pemberian hadiah pujian. Hal ini sesuai dengan apa yang dimaksudkan oleh Brown dan Levinson (dalam Wijana, 2011:135--136) bahwa kesantunan berbahasa dapat dilakukan dengan menggunakan salah satu strategi memberikan hadiah berwujud rasa simpati dan pujian kepada lawan tutur ketika berbicara.

Kelancaran komunikasi yang terdapat pada data [2] tidak hanya ditunjukkan oleh pesapa atau bibi, tetapi juga oleh yang disapa atau keponakan. Mendengar ungkapan yang dituturkan bibinya, keponakan tersebut juga menjawab dengan senang. Keponakan tersebut menggunakan strategi kesantunan berbahasa yang sifatnya melucu. Dia menambah suasana keakraban terjalin dengan erat.

\subsection{Kesantunan Berbahasa Tindak Tutur Konvival Meminta Maaf}

Data [3]

Teman (1) : "Luh maapakan anakulah. Kaca jandila ikam habis pacah. Tadi sudah dipasangakan tukang kalu”.

’Aluh maaf kan anaku ya. Kaca jendela kamu telah pecah. Tadi sudah dipasang tukang kan'.

Teman (2) : "Iih kada papa. Biasa kakanakan. Makasih jua sudah dipasangakan".

'iya tidak apa-apa. Biasa anak-anak. Terimakasih juga sudah dipasangkan ya'

Konteks tuturan: Tuturan dilakukan oleh dua teman yang bertemu di depan salah satu toko milik warga Banjar. 
Data [3] merupakan contoh penggunaan tindak tutur konvival yang terjadi antara dua warga Banjar. Teman (1) melakukan kegiatan bertutur dengan menggunakan maksim kemurahan yang mengutamakan kesalutan/rasa hormat pada orang lain dan rasa kurang hormat pada diri sendiri. Saat itu, teman (1) bertemu dengan teman (2). Anak teman (1) sebelumnya telah memecahkan jendela rumah teman (2). Dalam keadaan ini, teman (1) merasa tidak nyaman terhadap teman (2), dia pun mengeluarkan ujaran sebagai tanda permintaan maaf kepada teman (2) dengan ucapan: "Luh maapakan anakulah. Kaca jandila ikam habis pacah. Tadi sudah dipasangakan tukang kalu”, 'Aluh maaf kan anaku ya. Kaca jendela kamu telah pecah. Tadi sudah dipasang tukang kan'. Ucapan ini berwujud tindak tutur ekspresif. Hal ini sesuai dengan apa yang dimaksudkan Rahardi (2009:17) bahwa tindak tutur ekspresif adalah bentuk tindak tutur yang diutarakan untuk mengungkapkan perasaan penutur terhadap sesuatu keadaan. Fungsinya seperti berterima kasih, memberi ucapan selarnat atau bela sungkawa, meminta maaf, menyalahkan, memuji, dsb.

Teman (1) mengungkapkan rasa penyesalannya kepada teman (2) atas perbuatan anaknya yang menyebabkan terjadinya kerugian materi terhadap teman (2). Permintaan maaf ini sebagai upaya menjalin hubungan sosial yang baik terhadap teman (2). Apa yang diucapkan teman (1) bukan sekadar basa-basi tanpa fakta. Teman (1) tidak saja melakukan pernyataan permintaan, tetapi juga didukung dengan perbuatan yang berwujud memperbaiki kaca jendela.

Kesantunan berbahasa teman (1) sebagai pesapa yang menyapa teman (2) sebagai yang disapa adalah bagian sari keseharian warga Banjar Martapura. Budaya permintaan maaf seperti data (3) berdasarkan hasil pengamatan peneliti memiliki lima data. Masalah yang dimintamaafkan beragam. Salah satunya adalah data (3) tersebut. Budaya ini sangat penting dilestarikan di tengah masyarakat kita sekarang. Rasa saling memaafkan dan menyesali sebuah perbuatan yang bisa merugikan orang lain akan membuat jiwa kita menjadi bijaksana karena sangat menghargai kepentingan dan perasaan orang lain.

Kesantunan berbahasa yang dilakukan teman (1) kepada teman (2) merupakan budaya berbahasa yang menggunakan strategi kesantunan simpati kepada lawan bicara. Teman (1) menunjukkan rasa simpatinya tersebut melalui ujaran permintaan maaf. Dia berharap ungkapan permintaan maafnya ini akan bisa membuat hati teman (2) menjadi tenang, karena bisa saja akibat perbuatan anak teman (1) tersebut menyebabkan perasaan teman (2) menjadi jengkel. Akan tetapi, "kejengkelan" tadi mungkin bisa terobati melalui ujaran simpati teman (1) kepada teman (2). 
Sapaan teman (1) kepada teman (2) diujarkan dengan disertai mimik wajah yang ramah. Hal ini mengakibatkan jalan komunikasi berikutnya menjadi lancar. Dari apa yang terlihat saat itu, tampak wajah teman (2) tidak sedikit pun menunjukkan rasa marah. Dia menerima permintaan maaf tersebut dengan lapang dada. Bahkan, dia memberi pernyataan bahwa namanya anak-anak hal itu biasa saja terjadi. Jawaban teman (2) kepada teman (1) ini membuat hubungan sosial antara dua teman terlihat terjalin baik. Di sinilah kembali terbukti, kesantunan berbahasa sangat menentukan hubungan sosial antarwarga.

\subsection{Kesantunan Berbahasa Tindak Tutur Konvival Menyetujui}

Data [4]

Anak : "Ma, ulun jadi ai umpat lumba manulis puisi. Limbah ulun pikir kada salahnya pang ulun cuba”.

'Bu, saya jadi ikut lomba menulis puisi. Setelah saya pikir tidak ada salahnya saya coba'.

Ibu : "Iya, napa jar Uma kalu. Kada salahnya pang ikam umpat. Kalah manang kada jadi sual, nang panting ikam mancari pangalaman hulu. Siapa tahu kaina manang. Apa nyanyat tuh handak umpat tarus”.

'Iya, apa kata Ibu kan. Tidak ada salahnya lah kamu ikut. Kalah menang tidak menjadi masalah, yang penting kamu mencari pengalaman dulu. Siapa tahu nanti menang. Apa ketagihan tuh ingin ikut terus'.

Konteks tuturan : Tuturan terjadi antara seorang ibu dengan anaknya dalam rumah

Data [4] merupakan contoh penggunaan tindak tutur yang bertujuan sosial antar kerabat. Seorang anak melakukan pernyataan setujunya atas usulan si ibu. Saat itu, seorang ibu menyuruh anaknya untuk ikut lomba menulis puisi di salah satu lembaga pemerintah. Awalnya, si anak menolak usulan tersebut karena takut dan malu jika akan mengalami kekakalahan. Namun, setelah dia pikir-pikir, akhirnya berubah pikiran. Si anak pun akhirnya mengujarkan tuturan sebagaimana data [4]: "Ma ulun jadi ai umpat lumba manulis puisi. Limbah ulun pikir kada salahnya pang ulun cuba”, 'Bu saya jadi ikut lomba menulis puisi. Setelah saya pikir tidak ada salahnya saya coba'.

$\mathrm{Si}$ anak mengujarkan pernyataan persetujuan ini dengan menggunakan jenis tindak tutur asertif. Tujuannya adalah menjalin hubungan yang baik dengan si ibu yang sebelumnya dia rasa kurang senang akibat penolakannya untuk ikut lomba menulis puisi. Setelah si anak mengucapkan pernayataan seperti yang terdapat pada data [4], wajah ibu yang sebelumnya tampak sedih dan tidak banyak bicara, terlihat sekali menjadi berubah. Senyum sumringah 
menghiasi wajah si ibu. Bahkan, Si ibu setelah tuturan itu terjadi menjadi lancar bicaranya, dia memberi nasihat bagaimana caranya memenangkan perlombaan menulis puisi.

Apa yang dilakukan oleh si anak pada data [4] merupakan sebuah kesantunan berbahasa yang menggunakan strategi persetujuan. Hal ini sesuai dengan pendapat Brown dan Levinson (dalam Wijana, 2011:135--136) bahwa terdapat beberapa strategi kesantunan yang dapat dilakukan, seperti persetujuan. Si anak menyetujui usulan si ibu dengan mengujarkan pernyataan persetujuan: "Ma ulun jadi ai umpat lumba manulis puisi",'Bu saya jadi ikut lomba menulis puisi'.

Konteks tuturan pada data [4] merupakan cermin kesantunan berbahasa yang terdapat dalam keluarga Banjar. Si anak menggunakan prinsip kesantunan maksim kecocokan sebagaimana yang dimaksudkan Leech (dalam Jumadi, 2006:76). Si anak memberikan persetujuan ini sebagai wujud kecocokan seseorang dengan apa yang dinyatakan oleh orang lain. Prinsip kesantunan kecocokan ini akan sangat berpengaruh dalam sebuah komunikasi yang baik. Hal tersebut sudah dibuktikan dengan contoh [4] ini.

Data [4] ini juga menggunakan aturan kesantunan berbahasa sebagaimana yang dimaksudkan Chaer dan Leonie Agustina (2010:172). Si anak mengujarkan persetujuannya ketika pendaftaran baru dimulai dan saat dilihatnya si ibu mulai berubah sikapnya kepadanya. Ragam bahasa yang dia gunakan adalah bahasa santai dari bahasa daerah Banjar. Si anak memulai pembicaraan terlebih dahulu sebelum si berbicara. Si anak juga diam saat si ibu memberi nasihat kepadanya tentang lomba menulis puisi. Kualitas suara si anak terdengar lembut dan disertai dengan senyuman di wajahnya. Demikianlah, kelancaran komunikasi yang didasari oleh kesantunan berbahasa antara si anak dan si ibu ini sangat terlihat. Si ibu dan si anak bekerja sama dengan saling berbahasa santun saat terjadinya komunikasi tersebut. Si ibu pun menjawab dengan halus persetujuan si anak dengan ujaran: "Iya, napa jar Uma kalu. Kada salahnya pang ikam umpat. Kalah manang kada jadi sual, nang panting ikam mancari pangalaman hulu. Siapa tahu kaina manang. Apa nyanyat tuh handak umpat tarus", 'Iya, apa kata Ibu kan. Tidak ada salahnya lah kamu ikut. Kalah menang tidak menjadi masalah, yang penting kamu mencari pengalaman dulu. Siapa tahu nanti menang. Apa ketagihan tuh ingin ikut terus'. Keadaan ini sesuai dengan apa yang dimaksudkan oleh Rahardi (2009:220) yang menyatakan bahwa tindak tutur yang berdemensi sosiali akan berjalan dengan baik jika terjadi kerja sama yang kuat anatar peserta tutur. Salah satu bentuk kerja sama tersebut adalah dengan berprilaku sopan dan santun. Melalui perilaku sopan santun ini tentu setiap peserta tutur akan sangat memerhatikan pilihan kata yang 
diucapkannya sekaligus akan berupaya untuk menjaga perasaan antaranggota tutur ketika komunikais tersebut sedang terjadi.

\subsection{Kesantunan Berbahasa Tindak Tutur Konvival Mempersilahkan}

Data [5]

Tetangga (1) : "Ui amunnya handak liwat, liwat hajalah, kada usah marasa kada nyaman lah. Ini aku lagi mambaiki parit jalan kita nih, tampulu parai nah”.

'Hei kalau ingin lewat lewat saja ya, tidak usah merasa tidak enak ya. Ini aku sedang memperbaiki parit jalan kita ini, mumpung libur nah'.

Tetangga (2): "Oh iya, makasiiai mun kaya itulah, jalan paritnya dibaikiyakan. Aku handak ka pasar hululah maantar umanya. Kaina mun datang matan pasar aku danii. Daahh”.

'Oh iya, terimaksih kalau seperti itu ya, jalan paritnya diperbaikiakan. Aku mau ke pasar dulu ya mengantar ibunya. Nanti kalau sudah datang dari pasar aku bantu. Daah'.

Konteks Tuturan: Tuturan terjadi di tepi jalan antara dua tetangga

Data [5] terjadi antara dua tetangga yang rumahnya saling berseberangan. Ketika tuturan ini terjadi, tetangga (1) sedang memperbaiki parit yang berada di tepi jalan rumah mereka tersebut. Akibatnya jalan menjadi becek, sebagian badan jalan penuh lumpur dan beberapa potongan kayu. Menyadari kalau aktivitasnya di tepi jalan tersebut bisa membuat tetangga dekatnya merasa tidak nyaman -saat menggunakan jalan karena harus melewati dia yang sedang bekerja- dan untuk menjaga perasaan tetangga (2) keluarlah ujaran teman (1): "Ui amunnya handak liwat, liwat hajalah, kada usah marasa kada nyaman lah. Ini aku lagi mambaiki parit jalan kita nih, tampulu parai nah", 'Hei kalau ingin lewat lewat saja ya, tidak usah merasa tidak enak ya. Ini aku sedang memperbaiki parit jalan kita ini, mumpung libur nah'.

Ujaran tetangga (1) merupakan contoh penggunaan tindak tutur konvival yang memiliki tujuan sosial berwujud mempersilahkan. Tetangga (1) mengharapkan agar tetangga dekatnya tersebut tetap merasa nyaman berlalu lalang di depannya, meskipun dia sedang mengerjakan sesuatu untuk kepentingan bersama. Tetangga (1) mempersilahkan tetangga (2) agar melewati jalan itu tanpa perlu sungkan kepadanya. Tetangga (1) memberi alasan bahwa dia melakukan pekerjaan itu mumpung dia libur bekerja.

Berdasarkan situasi ujar, data [5] terdiri atas pesapa tetangga (1) yang menyapa tetangga (2). Teman (1) ini menggunakan jenis tindak tutur direktif atau perintah. Melalui tindak tutur direktif ini, tetangga (1) menjalin hubungan sosial dengan komunikasi yang baik. 
Penutur tidak melakukan basa-basi yang tidak sebenarnya. Dia melakukan basa-basi yang memiliki nilai kebenaran atas apa yang diucapkannya. Tetangga (1) memegang prinsip kesantunan berbahasa berupa maksim menghormati kepentingan orang lain. Kondisi ini sesuai dengan apa yang dimaksudkan Leech (dalam Jumadi, 2006:115) bahwa maksim menghormati kepentingan orang lain adalah penutur dalam berbahasa menggunakan pikirannya dalam memilih kata-kata yang memiliki tujuan agar menjaga perasaan orang lain demi hubungan sosial yang lebih baik.

Berdasarkan data [5] ini, budaya saling menghargai masih ada dalam kehidupan masyarakat Banjar di Kelurahan Sekumpul. Tetangga (1) sangat menghormati kepentingan tetangga (2) yang juga menggunakan jalan tersebut. Berdasarkan pendapat Brown dan Levinson (dalam Wijana,2011:135--136), konteks ini menggunakan strategi kesantunan dengan memberi perhatian kepada lawan bicara. Tetangga (1) memberi perhatian kepada tetangga (2) tentang kebutuhannya terhadap jalan yang paritnya sedang diperbaiki tersebut.

Selanjutnya, aturan yang terdapat dalam kesantunan berbahasa sebagaimana yang dimaksudkan Chaer dan Leonie Agustina ( 2010:172) terdapat pada data [5]. Tetangga (1) melakukan apa yang harus dikatakan pada waktu melihat tetangga (2) ketika dia sedang memperbaiki parit di tepi jalan mereka. Apa yang dilakukannya ini memang bagian dari budaya masyarakat Banjar pada umumnya. Bahasa yang dia gunakan adalah bahasa santai dengan menggunakan bahas daerah Banjar. Bahkan dia menyatakan agar tetangga (2) tidak usah sungkan melewati jalan tersebut. Tetangga (1) mengujarkan tuturannya dengan diiringi senyum di wajahnya dan intonasi suara biasa. Kualitas fisik dan intonasi suara ini bagian yang bisa juga menentukan sebuah bahasa santun atau tidak.

Tanggapan tetangga (2)mendengar ujaran tetangga (1) menunjukkan komunikasi dan relasi sosial berikutnya berjalan lancar. Hal ini dibuktikan dengan pernyataan tetangga (2) yang berintikan kalau dia mengucapkan rasa terimakasihnya karena parit mereka diperbaiki, dan dia juga berjanji akan ikut membantu tetangga (1) setelah dia selelsai mengantar istrinya ke pasar. Bahkan, tetangga (2) ini diakhir komunikasi melakukan strategi kesantunan berbahasa melucu. Dia menggunakan kata dan bertindak mendadahkan tangan seperti anak kecil.Senyum bersama terlihat saat itu.

\subsection{Kesantunan Berbahasa Tindak Tutur Konvival Menyapa}

Data [6]

Lurah : "Ui Mama Iwan, handak kamana piyan, Ulun badahulu Nah".

'Hei Mama Iwan, ingin kemana Anda. Saya duluan, Nah'.

Mama Iwan :"Uuh iya, Pambakalai, handak ka warung nukar acan, nah" 
'Ooh iya Pak Lurah, ingin ke warung beli terasi, nah'.

Konteks Tuturan: Tuturan terjadi di jalan desa Kelurahan Sekumpul

Data [6] merupakan contoh pelaksanaan tindak tutur yang bertujuan sosial. Konteks tuturan ini terjadi antara seorang lurah kepada warganya. Ketika itu, lurah sedang mengendarai kendaraannya menuju kantor kelurahan. Di tengah jalan, dia melihat seorang warganya yang usianya lebih tua dari dia, yaitu Mama Iwan yang sedang berjalan kaki dengan arah yang sama. Melihat warganya berjalan kaki sementara dia berkendaraan, lurah tersebut lalu menyapa: "Ui Mama Iwan, handak kamana piyan, Ulun badahulu, Nah, 'Hei Mama Iwan, ingin kemana Anda. Saya duluan, Nah'.

Ujaran Lurah pada data [6] berisi ungkapan sapaan kepada lawan bicara yaitu Mama Iwan. Bentuk kegiatan bertutur ini sebenarnya berwujud basa-basi semata. Lurah tidak benarbenar ingin mengetahui ke mana tujuan warganya tersebu. Namun, demi terjalinnya hubungan yang baik antarwarga dia pun mengajukan ujaran tersebut.

Ujaran yang berjenis direktif pada data [6] merupakan contoh terjadinya kesantunan berbahasa yang tidak mengenal status sosial. Lurah sebenarnya memiliki status sosial yang tinggi dibandingkan warganya. Dia tanpa memandang pangkatnya tersebut berkenan menegur sapa warganya tersebut. Budaya santun ini sangat baik untuk terus dilestarikan demi terwujudnya hubungan sosial yang baik antarwarga. Apa yang terjadi pada data [6] sesuai pula dengan apa yang dinyatakan oleh Anwar (1984) bahwa tindak tutur bertujuan sosial, contohnya adalah basa basi. Basa-basi ialah kata-kata yang berfungsi sebagai pemertahanan suasana yang baik saat penutur bahasa berada dalam satu waktu dan satu tempat. Selanjutnya, Arimi (1998) menyatakan bahwa kata-kata mempertahankan suasana yang baik ini terdiri atas basa-basi murni yang sesuai dengan kenyataan dan basa-basi yang tidak sesuai dengan kenyataan. Rahardi (2017:11) menyatakan bahwa tindak tutur yang bertujuan sosial ini atau disebut dengan bahasa kefatisan merupakan sesuatu yang sangat penting kehadirannya demi kelancararan komunikasi.

Maksim kebijakan berbahasa telah dilakukan pula oleh lurah pada data [6]. Lurah menggunakan pilihan kata Mama Iwan sebagai wujud penghormatan kepada warga yang usianya lebih tua, dia tidak memanggil nama langsung terhadap lawan bicaranya tersebut. Kearifan berbicara lurah ini sesuai pula dengan apa yang dimaksudkan Leech (dalam Jumadi, 2006:76) tentang penggunaan prinsip kesantunan berbahasa, yaitu menyatakan salah satu aturan atau maksim dalam prinsip kesantunan yaitu (1) maksim kebijakan yang mengutamakan kearifan bahasa. 
Kearifan bahasa yang dilakukan lurah ini kalau melihat pendapat Brown dan Levinson (dalam Wijana, 2011:135--136) menggunakan strategi sapaan. Strategi ini sebagai upaya lurah agar bisa berbicara santun saat berada di waktu tersebut dengan warganya. Salah satu sapaan yang santun adalah menggunakan sapaan honorofik, yaitu menggantikan nama seseorang dengan nama yang lebih terhormat. Penggunaan pilihan kata yang disesuaikan dengan budaya masyarakat Banjar telah dilakukan oleh lurah. Sudah menjadi kebiasaan di Sekumpul, jika seseorang memanggil orang tua, maka dia akan menyebut nama anaknya. Hal ini sesuai dengan pendapat Geertz (1960) (dalam Yayuk, 2012:173) yang menyatakan bahwa sistem penggunaan bahasa yang mendasari kesantunan berbahasa dapat disebut "sopan-santun berbahasa" atau honorifics. Hal ini lazim diungkapkan dengan kata ganti orang, sistem sapaan, penggunaan gelar, dan sebagainya. Dalam beberapa bahasa, perbedaan tingkat sosial antara pembicara dengan si alamat/pendengar diwujudkan dalam seleksi kata dan/atau sistem morfologi kata-kata tertentu.

Berdasarkan data [6], sapaan tersebut mencerminkan budaya kesantunan yang membuat sebuah komunikasi dan hubungan sosial terjalin dengan baik. Penggunaan bahasa santai dan daerah yang dijadikan media pengantar sapaan ini membuat suasana menjadi terasa akrab. Keakraban ini ditimpali dengan balasan jawaban dari Mama Iwan yang memberi jawaban dengan ramah juga: “Uuh iya, Pambakalai, handak ka warung nukar acan nah", 'Ooh iya Pak Lurah, ingin ke warung beli terasi, nah'. Contoh data [6] inilah yang dimaksudkan oleh Rahardi (2009:220) sebagai tindak tutur yang berdemensi sosial. Hal tersebut akan berjalan dengan baik jika terjadi kerja sama yang kuat antarpeserta tutur. Salah satu bentuk kerja sama tersebut adalah dengan berprilaku sopan dan santun.

\subsection{Kesantunan Berbahasa Tindak Tutur Konvival Mengucapkan Selamat}

Data [7]

Teman (1) : : Salamatlah, anak ikam sudah ditarima jadi PNS. Mudahan jua, nah anakku limbah lulus kuliah kaya itu jua nah”.

'Selamatlah anak kamu sudah diterima menjadi PNS. Mudahan juga, nah anakku setelah lulus kuliah seperti itu juga'.

Teman (2) : "Makasih banyak. Iinggih, mudah-mudahan bu ai. Amin".

'Terimakash banyak. Iya, mudah-mudahan, Bu ai. Amin' .

Konteks Tuturan: Tuturan terjadi di depan salah satu rumah warga Kelurahan Sekumpul.

Data [7] merupakan contoh pelaksanaan tindak tutur yang bertujuan sosial. Teman [1] melakukan aktivitas melakukan ucapan selamat kepada teman (2). Saat itu, teman (1) sedang menerima kedatangan teman (2) di beranda rumahnya. Di tengah perbincangan, teman (1) 
mengujarkan: "Salamatlah, anak ikam sudah ditarima jadi PNS. Mudahan jua nah anakku limbah lulus kuliah kaya itu jua nah, 'Selamatlah anak kamu sudah diterima menjadi PNS. Mudahan juga nah anakku setelah lulus kuliah seperti itu juga'.

Ujaran selamat dari teman (1) kepada (2) berdasarkan situasi ujar terdiri atas pesapa atau pengujar, teman (1) dan yang diberi ujaran teman (2). Hal ini memberikan gambaran bahwa kesantunan berbahasa masih terjadi di masyarakat Banjar Keluharan Sekumpul. Bentuk ujaran asertif yang sebenarnya tidak membutuhkan jawaban ini ternyata mampu menumbuhkan rasa keterikatan sosial antarwarga. Keterikatan sosial ini diwujudkan dengan saling menjalin komukasi secara santun.

Contoh [6] menunjukkan rasa simpati atas keberhasilan orang lain telah melahirkan kesantunan berbahasa. Prinsip kesantunan ini digunakan oleh teman (1) kepada teman (2) karena keberhasilan anak teman (2) yang sudah menjadi PNS. Rasa iri dengki tidak terdapat dalam konteks tuturan ini. Teman (1) mengucapkan selamat seraya berharap anaknya setelah lulus kuliah akan jadi PNS juga. Ungkapan santun yang terdapat dalam data [6] sesuai dengan apa dimaksudkan Leech (dalam Jumadi, 2006:76) yang menyatakan bahwa salah satu aturan atau maksim dalam prinsip kesantunan adalah maksim kesimpatisan yang mengutamakan rasa simpati pada orang lain. Dengan menerapkan prinsip kesopanan ini, orang tidak lagi menggunakan ungkapan-ungkapan yang merendahkan orang lain sehingga komunikasi akan berjalan dalam situasi yang kondusif.

Strategi yang digunakan oleh teman (1) dalam kesantunan berbahasa pada data [7] ini adalah strategi simpati sebagaimana yang dimaksudkan Brown dan Levinson (dalam Wijana, 2011:135--136). Teman [1] dengan disertai kualitas suara lembut dan senyum ramah terlebih dahulu mengucapkan kata selamat meskipun teman (2) tidak menceritakan apa yang sudah terjadi dengan anaknya. Teman (1) mampu memilih waktu yang tepat di sela pembicaraan mereka dengan topik yang berbeda. Ujaran yang dipikirkan dengan menggunakan pilihat kata selamat tersebut telah mapu membuat teman (2) terharu. Saat peristiwa tutur tersebut terjadi, terlihat teman (2) matanya berkaca-kaca mendengar ujaran teman (1). Hubungan pertemanan semakin erat terlihat. Kepedulian akan keberhasilan teman (2) membuat kesantunan berbahasa tercipta. Tanpa disadari oleh teman (1), rupanya dia melakukan aturan kesantunan berbahasa sebagaimana yang dikatakan oleh Chaer dan Leonie Agustina (2010:172) bahwa kesantunan berbahasa antara lain akan "mengatur" (1) apa yang harus kita katakan pada waktu dan keadaan tertentu kepada seorang partisipan tertentu berkenaan dengan status sosial dan budaya dalam masyarakat itu; (2) ragam bahasa apa yang paling wajar kita gunakan dalam situasi sosiolinguistik dan budaya tertentu; (3) kapan dan bagaimana kita 
menggunakan giliran berbicara kita dan menyela pembicaraan orang lain; (4) kapan kita harus diam; dan (5) bagaimana kualitas suara dan sikap fisik.

Selanjutnya, Ujaran santun teman (1) ini kemudian dibalas oleh teman (2) dengan ucapan: "Makasih banyak. Iinggih, mudah-mudahan, Bu ai. Amin", 'Terima kasih banyak. Iya, mudah-mudahan, Bu Ai. Amin'. Teman (2) menghargai ujaran teman (1). Dia bahkan turut mendoakan semoga hal yang sama juga terjadi kepada anak teman (1).

Dalam kondisi ini, terlihat bahwa sebuah hubungan sosial akan terjadin melalui komunikasi yang santun. Hal inilah yang dimaksudkan oleh Rahardi (2009:220) yang menyatakan bahwa tindak tutur yang berdemensi sosial ini akan berjalan dengan baik jika terjadi kerja sama yang kuat antarpeserta tutur. Salah satu bentuk kerja sama tersebut adalah dengan berprilaku sopan dan santun.

\section{Penutup}

Kesantunan berbahasa penting diperhatikan penggunaannya saat berkomunikasi. Kesantunan berbahasa ini akan membawa hubungan yang baik dalam kehidupan sosial selanjutnya. Hal ini dapat dilihat pada kehidupan masyarakat Banjar di Kelurahan Sekumpul, Kabupaten Banjar, Provinsi Kalimantan Selatan. Masyarakat Banjar masih melestarikan hubungan sosial yang baik dengan cara menggunakan kesantunan berbahasa. Wujud kesantunan berbahasa yang bertujuan sosial ini meliputi tindak tutur konvival menawarkan, terima kasih, memuji, meminta maaf, mempersilahkan, dan mengucapkan selamat. Ragam wujud tuturan konvival ini dituturkan dengan ragam jenis tindak tutur dan strategi kesantunan berbahasa.

\section{Daftar Pustaka}

Anwar, Khaidir. (1984). Fungsi dan Peranan Bahasa: sebuah Pengantar. Yogyakarta: Gadjah Mada University Press.

Arimi, Saila. (1998). Basa-Basi dalam Masyarakat Bahasa Indonesia.Yogyakarta: UGM.

Baryadi, I. Praptomo. (2013). Bahasa, Kekuasaan dan Kekerasan. Yogyakarta: Universitas Sanata Dharma.

Chaer, Abdul dan Agustina. (2010). Sosiolinguistik: Perkenalan Awal. Jakarta: Rineka Cipta.

Djasudarma, T. Fatimah. (2006). Metode Linguistik: Ancangan Metode Penelitian dan Kajian. Bandung: PT Eresco. 
Jahdiah. (2013). "Prinsip Kerja sama dalam Transaksi Jual Beli di Pasar Martapura”. Bunga Rampai Bahasa, Tahun 7: 25--45, Desember 2013, ISSN 978-979-069-155-1. Banjarbaru: Balai Bahasa Provinsi Kalimantan Selatan.

Kridalaksana, Harimurti. (2008). Kamus Linguistik. Jakarta: Gramedia.

Rahardi, R. Kunjana. (2017). Kepatisan Berbahasa: Kajian Pragmatik Tutur Sapa Keseharian Warga Masyarakat. Jakarta: Pusat Kajian Bahasa dan Budaya Universitas Katolik Indonesia Atmajaya.

Rohmadi, Muhammad. (2009). Pragmatik Teori dan Analisis. Yogjakarta: Lingkar Media Jogja.

Sudaryanto. (2011). Metode dan Aneka Teknik Analisis Bahasa: Pengantar Penelitian Wahana Kebudayaan Secara Linguistis. Yogyakarta: Duta Wacana University Press.

Sugiyono. (2011). Metode Penelitian. Bandung: Alfabeta.

Sugono, D., dkk. (2008). Kamus Besar Bahasa Indonesia: Edisi Keempat. Jakarta: PT Gramedia Pustaka Utama.

Tarigan, Henry Guntur. (2009). Pengajaran Pragmatik. Bandung: Angkasa.

Wijana, I Dewa Putu. (2011). Pengantar Semantik Bahasa Indonesia. Yogyakarta: Pustaka Pelajar.

Yayuk, R. (2012). "Maksim Kesopanan dalam Tuturan Penumpang dan Tukang Ojek di Pasar Hanyar Kota Banjarmasin”. Bunga Rampai Bahasa, 149--174. Banjarbaru: Balai Bahasa Provinsi Kalimantan Selatan.

Yule, George. (1996). Pragmatics.(Terjemahan Jumadi). (2006). Pragmatik. Banjarmasin: Unlam.

Yusri. (2016). Ilmu Pragmatik. Yogyakarta: Deepunlish.

Zaini, Ahmad(Ed). (2008). Kesantunan Direktif Bahasa Banjar. Banjarbaru: Balai Bahasa Banjarmasin. 